\title{
TERMINOLOGIA
}

\section{Human Chorionic Somato-Mammotropin (HCS), Proposed Terminology for Designation of a Placental Hormone}

Recent studies of JosIMovICH ${ }^{1}$, GRUMBACH and KAPLAN ${ }^{2}$ and their. co-workers on the human placenta, indicate that it contains a new protein hormone, possessing some biological properties in common with those of human pituitary growth hormone $(\mathrm{HGH})$ : (a) it exhibits lactogenic activity in the pigeon and pseudopregnant rabbit 1 . (b) It has growth-promoting activity as indicated by the rat body weight and costal cartilage assays ${ }^{2-4}$. (c) It is active as a luteotropic agent. ${ }^{5}$. (d) It stimulates protein synthesis in a cell-free system ${ }^{9}$. (e) It facilitates lipolysis in vivo ${ }^{6}$ and in vitro? (f) Although it has low potency in promoting growth, it enhances the activity of $\mathrm{HGH}^{3,8}$ in the rat. (g) It causes hypoglycemia ${ }^{4}$ in the rat. (h) When administered in amounts sufficient to raise the concentration in plasma to that found in late pregnancy, it promotes nitrogen, potassium, phosphorus, and calcium retention, as well as calciursis, in patients with hypopituitary dwarfism ${ }^{*}$ in whom it also has been shown to have a diabetogenic and insulinogenic effect. (i) Immunologically ${ }^{1,2}$, the hormone cross-reacts with rabbit antisera to human growth hormone.

The hormone has been obtained in highly purified form ${ }^{3,4,10,11}$ and shown to be a protein of mol. wt. about 20,000 with a single polypeptide chain. The $\mathrm{NH}_{2^{-}}$and $\mathrm{COOH}$-terminal amino acid residues were found to be valine and phenylalanine respectively and certain amino acid sequences of the hormone were shown to be similar to that of $\mathrm{HGH}^{12,13}$. The hormone has been named as human placental lactogen (HPL) ${ }^{1}$ and chorionic growth hormone-prolactin (CGP) ${ }^{2}$ and has also been designated as purified placental protein (human) $[\mathrm{PPP}(\mathrm{H})]^{3}$ and placental protein 4 .

In order to eliminate confusion by the use of different terms for the same hormone, we wish to propose that henceforth the hormone be called human chorionic somato-mammotropin. Since the hormone is located in the syncytiotrophoblastic layer of the human placenta ${ }^{14}$, the same cells producing human chorionic gonadotropin (HCG) and since it has both growth hormone (somatotropin) and lactogenic hormone (mammotropin) activities, it would be practical to designate a term which is in line with the established terminology for a gonadotropin produced by the human placenta. Hence, the name human chorionic somato-mammotropin (HCS) indicates the origin of the hormone as well as the biological properties now known ${ }^{15}$.
Zusammenfassung. Es wird vorgeschlagen, dass das von verschiedenen Forschern als ehuman placental lactogen", "chorionic growth hormone prolactin", "purified placental protein (human)" usw. bezeichnete plazentare Hormon "chorionic somato-mammotropin (HCS)" benannt wird.

C. H. LI, M. M. GRUMBACH, S. L. KaPLAN, J. B. Josimovich, H. Friesen and K. J. Catt

University of California, San Francisco (California 94122), University of Pittsburgh, Pittsburgh

(Pennsylvania, USA), Mc Gill University,

Montreal (Canada), and Monash University, Melbourne (Australia), 9 September 1968.

1 J. B. Josimovich and J. A. MacLAREn, Endocrinology 71, 209 (1962).

2 S. L. Kaplan and M. M. Grumbach, J. clin. Endocr. Metab, 24, 80 (1964). - M. M. Grumbach and S. L. Kaplan, Trans. N.Y. Acad. Sci. 27, 167 (1964).

2 J. R. Florini, G. Tonelli, C. B. Breuer, J. Coppola, I. Ringler and P. H. BELL, Endocrinology 79, 692 (1966).

4 H. Friesen, Endocrinology 76, 369 (1965).

5 J. B. Josimovich and B. L. Brande, Trans. N.Y. Acad. Sci. 27, 161 (1964).

6. M. Grumbach, S. L. Kaplan, C. L. Abrams, J. J. Bell and F. A. Conte, J. clin. Endocr. Metab. 26, 478 (1966).

7 J. R. Turtle, G. Litrleton and D. M. Ktrnis, Clin. Res. 14, 289 (abstr.) (1966)

8 J. B. Josimovich, Endocrinology 78, 707 (1966).

M. M. Grumbach, S. L. Kaplan, J. J. Sctarra and I. Burr, Ann. N.Y. Acad. Sci. 148, 501 (1968).

$10 \mathrm{H}$. Comen, M. M. Grumbach and S. L. Kaplan, Proc. Soc. exp. Biol. Med. 117, 438 (1964).

11 K. J. Catt, B. Moffat, H. D. Niall and B. N. Preston, Biochem. J. 102, 27o (1967).

12 K. J. Catt, B. Moffat and H. D. Niali, Science 157, 321 (1967). 13 L. M. Suerwood, Proc. natn. Acad. Sci. 58, 2307 (1967).

14 J. J. Sciarra, S. L. Kaplan and M. M. Grumbach, Nature 199, 1005 (1963).

15 This communication was the result of a discussion during a Round Table Conference on Human Placental Lactogen held at the University of Siena on September 1967 which was arranged by Drs. E. F. MÚl.ter and P. Neri.

\section{PRO EXPERIMENTIS}

\section{Sterile Submerged Culture of Some Graminaceous Plantlets}

Sterile cultures of various plant organs, such as roots, stems or embryos, in synthetic agar or liquid media have been described by a number of authors 1,2 , but the submerged, shaken culture of whole plants has not yet been reported.

Seeds of wheat (Triticum vulgare, var. Mentana) were sterilized for $5 \mathrm{~min}$ in a $0.1 \%$ solution of $\mathrm{HgCl}_{2}$. The embryos, separated from the seed by means of a sterile needle after repeated rinsing with distilled water, were placed in $100 \mathrm{ml}$ of White's medium (WHITE ${ }^{2}$, p. 74) in 500-ml flasks: the latter were on a shaker rotating at $200 \mathrm{rpm}$ and with a throw of $5 \mathrm{~cm}$. The cultures were incubated at $27^{\circ} \mathrm{C}$ and in the dark. Under these conditions, the embryos started germinating after $24-48 \mathrm{~h}$. After

1 J. R. Gautheret, La culizure des tissues végétauz (Masson \& Co., Paris 1959).

2 P. R. Winte, The Cultivation of Animal and Plant Cells (The Ronald Press Company, New York 1954). 